\title{
The Role of Mindfulness and Digital Detox to Adolescent Nomophobia
}

\author{
Dewi Khurun Aini ${ }^{1}$, Baidi Bukhori ${ }^{2}$, Zainudin Abu Bakar ${ }^{3}$ \\ Universitas Islam Negeri Walisongo ${ }^{1,2}$, Universiti Teknologi Malaysia ${ }^{3}$ \\ \{dewi_khurun@walisongo.ac.id'1 ,baidi_bukhori@walisongo.ac.id²,p-zain@utm.my ${ }^{3}$ \}
}

\begin{abstract}
Nomophobia is an important study in the digital era. Nomophobia is related to an individual's anxiety when they are away from gadgets and has an impact on daily activities. This study aims to empirically examine the effects of mindfulness and digital detox on nomophobia in adolescents. The hypothesis proposed in this study is that there is an effect of mindfulness and digital detox on nomophobia in adolescents. The subjects of this study consisted of 40 people. The analytical methods used is the paired sample T-test and covariate analysis. The results of the analysis showed that the study showed that there was a significant effect of mindfulness and digital detox treatment on the decrease in adolescent nomophobia. The changes were different from the two groups, with the value obtained $t=-18.084 ; F$ value $=171,809 ;$ where $p=0.000\{p<0.05\}$. This shows that there is a significant effect of mindfulness and digital detox interventions on nomophobia in adolescents. After the intervention, the level of nomophobia in the experimental group was lower than the control group, so that the hypothesis in this study was accepted. This research has theoretical implications, namely, further exploration of how the factors that influence nomophobia, and the provision of significant treatments reduces the nomophobia.
\end{abstract}

Keywords: Nomophobia; Mindfulness And Digital Detox; Adolescent

\section{Introduction}

Science and technology are increasingly developing, making it easier for humans to communicate with other people. One example of this form of technological development is the smartphone. The increase in smartphone users in the world every year can be seen from the survey data, in 2018 there were 3.6 billion active smartphone users, and in 2019 this increased to 3.8 billion active smartphone users. [1] The same thing also happened in Indonesia, there were 83.5 million smartphone users in 2018 and in 2019 there was an increase to 92 million users. Indonesia is ranked fifth based on data from a research institute that listed the largest smartphone users in the world. Data reported by Horace H. Dediu wrote that the population of androids has reached more than 1 billion, while iOs has reached 700 million [2].

The results of a survey conducted by UNICEF (2017) with partners, including the Ministry of Communication and Information Technology, Harvard University, USA said that as many as $98 \%$ of children and adolescents claim to 'know about the internet', and $79.5 \%$ of them are 
internet users, and record numbers the high use of smartphones in the 'smartphone addiction' category. The results of the study found that $53 \%$ of cellphone users in the UK tend to experience anxiety when they are far from their gadgets, run out of battery, and when they do not have internet coverage [3]. The same thing was also revealed that the effect of smartphone addiction affected achievement motivation, and the intensity of reading text books on academic achievements.[4]

Based on the survey results, adolescents show prevalence and incidence rates on specific problems related to biopsychosocial health, which in this case relates to anxiety when away from gadgets. In connection with the phenomenon of smartphone addiction, it also happens a lot in Indonesia. Nomophobia has been considered a disorder of the modern world, suggesting an anxiety disorder.

The prevalence rate of adolescents in Indonesia tends to use mobile phones will increase more intensively, which results in less attention to the real world around them. Adolescence is a period that influences the formation of one's self-concept. Children will increasingly interact with their environment and not only will they give meaning to their environment, but they will also receive a lot of input from the environment itself. At this age, there are many changes that will have an impact on a person's psychological condition. For example, changes in body shape in girls will make them pay more attention to their appearances. They will also compare their appearances with the appearance of their friends. Responses from other people about themselves will also have their own impact, all of which will contribute to the formation of a teenager's self-concept. When the focus and attention is greater on interactions in cyberspace, this causes less direct interaction.

With regard to awareness and care for the surrounding community, many young people today do not care about the conditions around them. And the same thing in Indonesia in general, Central Java as one of the provinces whose population has also increased in the use of gadgets, it has even become a basic necessity. Similar phenomena also occur in Semarang City in general, and in Jatisari Subdistrict, Mijen District, Semarang City, Central Java Province, based on preliminary research and FGD and interviews with parent associations, who also complain about the same thing, which is related to smartphone addiction. This results in children and adolescents being lazy in their daily activities and less concerned about the conditions of their surroundings. Regarding the impact that can be inferred from excessive access to a smartphone, a smartphone that is used without control can also trigger feelings of anxiety and feelings of loss if you are far from a smartphone [5]. The same thing was also stated by Nathaniel Barr and Gordon Pennycook that dependence on the internet can reduce mental intelligence, anxiety and the ability to solve problems [6]. Anxiety when away from the smartphone refers to nomophobia.

Nomophobia comes from the word "no mobile phone phobia", which is the fear of being away from a smartphone. If someone is in a place where there is no internet network, balance or even worse, is running out of battery, lack of internet quota, then that person feels anxious [7];[8] define nomophobia as a feeling of anxiety due to the unavailability of devices such as computers or virtual communication devices, in this case it is more related to cell phones. Goleman said that the cause of the distraction of attention was due to the lack of emotional connections between individuals in interacting with other individuals [23].

Theoretically, this research is expected to be able to provide readers with insight and new information for the psychology program, especially for the mental health development regarding the nomophobic syndrome, and other sciences, as well as being a reference for other researches. Practically, this research is expected to be able to continuously apply mindfulness and digital detox so that it is expected to reduce nomophobia in adolescents, and to realize 
mental health personally, family and society. Religious discourse related to religious moderations and the way the younger generation responds to the New Era Industry 4.0: Opportunities and Challenges.

In connection with the challenges in addressing the phenomenon of nomophobia among adolescents, nomophobia affects physical, psychological, and social health such as lack of sleep, eye fatigue, insomnia, headaches, hearing loss, lack of tolerance, withdrawal from the social environment, difficulty controlling impulses, concentration problems, escape from problems, and decreased concentration (same meaning) in everyday life [9]. The number of negative impacts means that the nomophobia variable is an important concern for immediate treatment. Research that discusses nomophobia with a mindfulness approach and digital detox has not been found.

This study combines mindfulness and community-based digital detox (MFDD) to reduce nomophobia in adolescents living in the area of Jatisari Mijen Village, Semarang which is listed as one of the communities that has teenagers based on the results of pre-elementary research surveys and FGD results. Generally, of a number of adolescents are in the criteria for having severe nomophobia that has not been found in other studies. This research is expected to be able to produce useful scientific findings, namely finding effective interventions to reduce nomophobia in adolescents.

\section{Method}

The approach of this research is quantitative research methods with true experimental design. Quantitative method is a scientific method that tests certain theories deductively by examining the relationship between variables and variables measured by certain instruments. Based on the background of this problem, the formulation of the problem in this study is whether mindfulness and digital detox (MFDD) interventions affect nomophobia in adolescents? The aim of this study was to empirically test the influence of mindfulness and digital detox interventions on the nomophobic syndrome experienced by adolescents.

The studies that are related to the research being studied include: first, Sakirogulu [10] conducted a study with the title: "The mediator effect of mindfulness awareness on the relationship between nomophobia and academic university adjustment levels in college students". The results in this study indicated that when an individual has high mindfulness, the individual will realize the effect of nomophobia, so that he can prepare himself for possible obstacles that arise due to nomophobia. (2). [11] conducted a research entitled: SelfManagement Training to Reduce Nomophobia in Students. The results in this study indicate that there are differences in the level of nomophobia among students before and after being given training in the experimental group, so that the self-management training can reduce nomophobia in students. From this study, researchers used mindfulness and digital detox as their intervention. (3) [12], conducted a study entitled: Detection of K-complexs and sleep spindles (Detox) using sparse optimization. The results of this study indicate that detoxification is a fairly good method for treating sleep disorders. Smartphone addiction and achievement motivation directly affect the intensity of reading academic textbooks, and smartphones addiction, achievement motivation, and the intensity of reading academic textbooks directly affect the academic achievement [13].

Based on some of the studies above, the researcher believes that there are several differences made by researchers when compared to the studies that have been carried out, the researcher uses the foundation of efforts to cultivate individual self-awareness (pre 
contemplation and post contemplation) emphasizing clarity and balance of mind, practicing patience and inner silence so that stress and anxiety will decrease [14]; mindfulness has a positive and significant role on every dimension of psychological well-being in adolescents, especially in the dimension of environmental control.

The implications of the research results will be explained at the end [15]. Gratitude can improve adolescents' self-concept caused by social comparisons when using social media [16]. The effect of type D personality (social disinhibition and negative affective), self-esteem, and fear of missing out (FoMO) on Instagram addiction among adolescents (where is the effect?) [17]. As well as social support in continuously supporting the implementation of mindfulness and digital detox interventions to reduce nomophobia syndrome experienced by millennial adolescents. The differences are related to the research location, good approach, cognitive, affective, behavior that is manifested in mindfulness and also commitment to digital detox.

The data from the research is in the form of numbers and in this method uses statistical analysis [18]. In this study, the researcher uses an experimental research design. The purpose of using the experimental method in this study was to examine the causal relationship by manipulating one variable, namely the mindfulness intervention and digital detox (MFDD) in the experimental group, and comparing the results with the control group that did not experience manipulation, as well as providing treatment to obtain the desired results.

Systematic changes in the traits (independent variable values) are meant to be manipulated in the study. The research used true experiment designs, where the main characteristic was in determining the samples used for the experimental group as well as the control group which were taken randomly from a predetermined population. Furthermore, to increase external validity, this study used random choice to select the involved subjects (participants) so that generalization was better. The scale used in this study to measure the role of intervention is the nomophobia scale, also known as the Nomophobia Questionnaire (NMP-Q). The nomophobia score is obtained from the results of a Nomophobia Questionnaire which must be answered and filled in by the subjects.

The nomophobia scale is divided into 24 statements which are grouped into four dimensions, namely the inability to communicate, unable to access information, a loss of connectivity, as well as feeling comfortable giving up on a device (smartphone). This research was conducted using a re-experimental design (pre-test and post-test control group design). The re-experimental design consisted of measurements or initial observations before the treatment was given and after the treatment in the treatment group and the control group were conducted [19]. The randomization process was carried out as a control for the subjects' innate factors and to equalize the characteristics of the subjects in the experimental group (KE) and the control group (KK). The advantage of this research design is that it controls the characteristics of the subjects [20].

\section{Results and Discussion}

The results of the validity trial using the correlation test between items on the nomophobia scale are as follows: the table of test results for the item with the correlation between the item and the total test score of the measuring instrument. From the results of the calculation, it can be seen that the significance value is $<0.05$, so it is said that the scale measuring instrument in this study is valid. In addition to the validity test, there is a reliability test. Reliability comes from the word reliability (seems redundant), a reliable measurement that is reliable, that is, is a 
measurement that is able to produce data that has a high level of reliability. Using the same measuring instrument, the theoretical value of the reliability coefficient ranges from 0.0 to 1.0 . the closer to 1.0 , the higher the reliability and vice versa. The closer to 0.0 , the lower the reliability[21]. The nomophobia scale item after testing showed a score of 0.935 . From the results of the nomophobia scale reliability score based on the validity and reliability test trials on the nomophobia scale, it can be concluded that the items on the scale meet the valid and reliable criteria. This means that the items of these items are able to measure what you want to measure in the nomophobia category variable. In addition, the item items also have very high reliability, namely with a value greater than 0.6 .

The procedure stages of experimental research that will be carried out can be explained as follows: (1). Screening: Screening is done to determine the condition of the subject before the research is carried out. (2). Randomization: Determination of the sample in the study using stratified random sampling technique. Randomization, From the results of the initial pretest conducted by the researcher on 40 participants, one of them was put into KE and the other was randomly assigned to the KK. So after randomization, the subjects were put in groups [20]. (3).

Pilot study (Research Trial); (4). Pre-test (Measurement of Initial Ability): The pretest uses the nomophobia scale to determine the level of the nomophobia score. The pre-test was carried out with the aim of knowing the initial score of the nomophobia level. The score was obtained from the nomophobia scale calculation with low, medium, and high criteria; (5). Giving treatment /Experiment: Treatment in the form of mindfulness intervention and digital detox was only given to subjects in the experimental group. The treatment was given in 8 meetings over a period of two weeks. The treatment was given to the subjects who were divided into 2 groups (20 subjects in one classroom) with the proportion of each one co-facilitator per subject.

At each meeting the subjects in the experimental group will be given socialization material about nomophobic literacy; mindfulness literacy; digital detox literacy; implementing the application of mindfulness interventions and digital detox part 1; implementing the application of mindfulness and digital detox interventions; part 2; implementation of mindfulness intervention and digital detox part 3; implementation of mindfulness intervention and digital detox part 4; implementation of the application of mindfulness and digital detox interventions part 5. Then at the end of the experimental stage the subjects are expected to be able to apply mindfulness and digital detox continuously, so that it is expected to reduce the level of nomophobia of adolescents who have high categories; (6). Post-test (Final Ability Measurement): The post-test stage is the same as the pre-test. The implementation of this posttest aims to determine the difference in the level of nomophobia score before and after giving treatment to the experimental group and also to determine the differences in the level of nomophobia between the experimental group and the controlled group.

The concept of mindfulness explained by the facilitator is a definition of mindfulness and attitudes that need to be developed in mindfulness from Kabat Zin [14], [22] [22] . Kabat explained that mindfulness is a form of pure attention, on a goal, in the moment [14], and without judgment. Furthermore, in practicing mindfulness it is necessary to develop nine basic attitudes, namely, without judgment, patience, openness, trust, no ambition, letting go, accepting, being grateful, and generosity.

Mindfulness intervention is a meditation method consisting of a combination of affective, cognitive, moral, intrapersonal and interpersonal methods [23]. Baer [24] proved that there is a positive relationship between mindfulness and the treatment of various psychological disorders. Baer's opinion is reinforced by Kabbat-Zinn [25] which states that mindfulness 
meditation practice aims to increase the ability to stay involved in current events without overevaluating them. The purpose of a mindfulness exercise program is to assist the individual in finding the right thing. The mindfulness method is also a way to become aware of one's own behavior, habits and reactions and is very useful for teenagers who experience anxiety when they are away from a smartphone. The mindfulness intervention that will be given to adolescents with Nomophobic syndrome refers to the mindfulness method to reduce stress and increase empathy for adolescents with Nomophobic syndrome [23] as intervention material.

In the era of 4.0, there were many challenges faced by the younger generation, in terms of implementing religious moderation and deradicalization in providing interventions. One of the approaches used includes was an awareness approach to adolescents in using gadgets wisely and the principle of usefulness. Mindfulness is a conscious mind that rests on scientific mechanisms, logic, rationality and analysis, and focuses on the whole self. When we are attentive, oriented to the present moment, sensitive to context (what happens when we are attentive?) [22].

The effectiveness of mindfulness and digital detox interventions as an approach to fostering awareness and tranquility of life which also emphasizes clarity and balance of mind, exercises patience, inner silence, so that stress and anxiety will decrease, in this case anxiety when far from a smartphone, is a rationale for researchers to develop a new intervention through this research. Mindfulness practice carried out in mindfulness, which is one activity at a time (fully aware and fully present). Individuals are aware of and choose to respond, because individuals have the freedom to choose what behavior to express. Individuals practice pauses between activities. Individuals try to focus on what is in control (thoughts, feelings, actions, and words); as well as trying to recognize the purpose of self-creation, to be meaningful and to find tranquility (meaningfull); individuals try to provide benefits or mission specifications that become the innate potential of the individual from birth.

Regarding the innate potential of birth, the factors that influence nomophobia are gender, self-esteem, age, and personality. While in this research, the novelty form is how to provide a support system by providing training in order to strengthen the personality of those who are prone to experiencing nomophobia, and strengthens self-esteem. Hurlock, suggested several characteristics of the adolescent period, namely: (1). As it is known that the adolescent period is a transitional period, adolescents experience transitions in several aspects, for example: transitions in a physical aspect; transitions in emotional life; transitions in emotional life; transitions in understanding; transitions in social life; transitions in moral values, and so on. (2). The teenage period is an unrealistic period [26]. So that with the right approach and according to their developmental tasks, it is hoped that it will help awaken adolescents to use smartphones wisely.

Based on the research results, the strong assumption is that the application of mindfulness provides several positive benefits to the quality of individual life. This is in accordance with the results of the study that mindfulness interventions and digital detox can reduce nomophobia in adolescents, where individuals feel happier in carrying out their activities; productivity in life is felt to be increasing with its various roles in society; and finally the individual feels healthier.

Mindfulness, can also be done as a habit in everyday life, and can be done in four ways, namely doing one activity at a time; is aware of an activity and chooses a response; focusingon what's in control; State your own goal ideas. So that when a person realizes and gets to know themselves more, the individual will know very well the purpose in life and in particular be wiser in using gadgets, so that they care more about the environment and avoid mistakes and create mental health problems. 
In addition, the results of this study prove that the awareness that arises through attention to a goal, at the moment and is not judgmental, enjoys every experience makes individuals enjoy and appreciate it more, and makes sense of every known activity, so that gradually it can reduce or count when they are far away from dagdets. The process of changing behavior itself can be formed between understanding (understanding, learning); conditioning (habit); modeling (provides examples), so that the results of this study also provide an explanation that, the implementation of digital detox that is planned and forced, gradually becomes a habit and the needs of each individual when focusing on one particular goal.

Moreover, with the mindfulness of mindfulness that is applied in the lives of adolescents, these adolescents will be increasingly formed into adolescents who are able to process emotions, understand themselves, and understand and interpret every activity, be it intellectual (thought), affective (feeling), speech, and activity (physical / behavioral). This agrees with what Maharani said, that mindfulness is proven to be effective for adolescents, among other things, in reducing stress; reduction of loneliness in adolescents in orphanages. Digital deox is a way to reduce dependence on electronic devices, especially dependence on social media. By doing a digital detox, it will give individuals the opportunity to relax, so that when they return to their activities they become more productive. Neither further research related to mindfulness nor the application of digital detox can be applied to other subjects

\section{Conclusions}

Based on the results of the research on the role of mindfulness and digital detox interventions on the tendency of nomophobia in adolescents using quantitative research methods with experimental research design with 40 adolescent subjects, the results of the initial screening of 40 adolescents who experience nomophobia which are in the moderate, high and very high category. It can be concluded that the MFDD intervention is very significant in reducing the tendency of nomophobia experienced by adolescents. The results of the differences in the Post-Test score were significant, meaning that there were differences between the two groups, with a value of $F=171.809 ; \mathrm{p}<0.05$.

When viewed from the mean, the Nomophobia of the experimental group has a lower mean than the mean of the controlled group. This means that after checking through descriptive statistics, it can be seen that the decrease in nomophobia in the experimental group looks very significant, which initially is very high, high and moderate to the level of nomophobia in the lower categories compared to the control group. The analysis showed that there was a significant difference in post-test scores by controlling the pre-test scores $(\mathrm{F}=$ $171.809 ; \mathrm{p}=0.000<0.05)$. Judging from the mean, the KE post-test score $(\mathrm{M}=58.70)$ was lower than the KK after controlling the pre-test score $(\mathrm{M}=24.43)$. It can be concluded that the treatment / treatment (treatment twice) / intervention significantly reduces anxiety.

The results of data analysis carried out on each of the 20 subjects (participants) in the experimental group (KE) and 20 subjects (participants) in the controlled group (KK) were as follows: For the experimental group, there were significant changes from before and after the treatment, namely decreased nomophobia. The intervention stimulates adolescents to increasingly find calm and meaningfulness in their lives, be it in thought, feelings, behavior, self-commitment, intrapersonal, and spiritual relationships so that feelings of anxiety being away from smartphones (nomophobia) diminish or gradually decrease.

However, for the control group that was not given treatment, there was no level of nomophobia, and there were differences in changes in nomophobia in the experimental group 
and the controlled group. The researcher uses the foundation of efforts to cultivate individual self-awareness (pre contemplation and post contemplation) emphasizing clarity and balance of mind, practicing patience, inner silence, so that stress and anxiety will decrease. The limitations in this study have not revealed the personality patterns of adolescents who have a tendency to experience nomophobia. The accuracy in providing the intervention will actually be applied in the real life of adolescents.

\section{Acknowledgements}

The researcher would like to thank those who have contributed a lot in this research, especially to:

1. Chancellor of UIN Walisongo Semarang who has provided research facilities in the form of budget research assistance for DIPA BOPTN UIN Walisongo Semarang in 2020

2. LP2M as an institution at UIN Walisongo Semarang which facilitates the research process from beginning to end.

3. Dean of the Faculty of Psychology and Health UIN Walisongo Semarang.

\section{References}

[1] A. . APJII), "https. Dipetik Maret 20, 2019, dari www. Apjil.or.id: https://www.apjii.or.id/content/read/39 /342/Hasil -Survei-Penetrasi-dan-PerilakuPengguna-Internet-Indonesia-2019.”( 2019)

[2] K. N. Sharen Gifary., "Intensitas Penggunaan Smartphone terhadap Perilaku Komunikasi," J. sosioteknologi, Vol.1, No. (2), (2015)

[3] Securenvoy, " $66 \%$ of the population suffer from Nomophobia the fear of being without their phone." (2012)

[4] F. M. N. Baidi Bukhori, Hamdan Said, Tony Wijaya, "The Effect of Smartphone Addiction, Achievement Motivation, and Textbook Reading Intensity on Students' Academic Achievement," Int. Assoc. Online Eng., pp. 66-80, (2019)

[5] Choliz, "Mobile-phone addiction in adolescence: The Test of Mobile Phone Dependence (TMD)," Prog Helath Sci, vol. 2, no. (1), pp. 33-44., (2012)

[6] G. Pennycook, "The brain in your pocket: Evidence that Smartphones are used to supplant thinking.," al Comput. Hum. Behav., vol. H. 478-480, (2015)

[7] C. Yildirim, "Exploring the dimensions of nomophobia: Developing and validating a questionnaire using mixed methods research," IOWA State University., (2014)

[8] E. King, A., Valenca, A., Silva, A., Sancassiani, F., Machado, S., \& Nardi, "Nomophobia: impact of cell phone use interfening with symptoms and emoticons of Clinical Practice \& Epidemiology in Mental Health," Clin. Pract. Epidemiol. Ment. Heal., vol. 10, no. 10, pp. 28-35., (2014)

[9] J. Bianchi, A., \& Philips, "Psychological Predictors of Problem Mobile Phone Use," Predict. Probl. Mob. Phone Use, Cyber Psychol. Behav., vol. 8, no. (1), pp. 3-51., (2005)

[10] T. Sakiroglu, M., Gulada, G., Ugurcan, S., Kara, N., \& Gandur, "The Mediator Effect of Mindfulness Awareness on The Relationship Between Nomophobia and Academic University Adjustment Levels in College Students.," Int. J. Psycho-Educational Sci., vol. 6, no. 3, pp. 69-79, (2017)

[11] S. Novitasari, D., Wahyuningsung, H., \& nugraha, "Pelatihan Manajemen Diri untuk 
Menurunkan Nomophobia pada Mahasiswa," Universitas Islam Indonesia, (2018)

[12] A. Ankit, P; Ivan, W; David, M; Indu, "Detection of K-complexes and sleep spindles (Detoks) using sparse optimization.," Detect. K-complexes sleep Spindl. using sparse Optim. J. Neurosci. Methods, vol. 251, (2015)

[13] Bukhori, B., Said, H., Wijaya, T. \& Mohamad Nor, "The Effect of Smartphone Addiction, Achievement Motivation, and Textbook Reading Intensity on Students' Academic Achievement.," iJIM, vol. Vol. 13, no. No. 9, pp. 66-80, (2019)

[14] J. Kabat-Zinn, Full catastrophe living: Using the wisdom of your body and mind to face stress, pain and illness. New York: Delacourt., (1990)

[15] Wenita Cyntia Savitri and R. A. Listiyandini, "Mindfulness dan Kesejahteraan Psikologis pada Remaja," Psikohumaniora, vol. Vol 2, no. No 1, (2017)

[16] J. S. Putra, "Peran Syukur sebagai Moderator Pengaruh Perbandingan Sosial terhadap Self-esteem pada Remaja Pengguna Media Sosial," Psikohumaniora, J. Penelit. Psikol., vol. Vol 3, no. No.2, pp. 197-210, (2018)

[17] W. R. \& I. Mulyani, "Instagram addiction in teenagers: The role of type D personality, self-esteem, and fear of missing out," Psikohumaniora J. Penelit. Psikol., vol. Vol 5, no. No 1, pp. 29-43, (2020)

[18] J. W. Creswell, Research Design Pendekatan Kualitatif, Kuantitatif, dan Mixed. Yogyakarta: Pustaka Pelajar, (2016)

[19] Latipun, Psikologi Eksperimen. Malang: UMM Press, (2002)

[20] D. Seniati, L., Psikologi eksperimen. Jakarta: Indeks, (2005)

[21] S. Azwar, Penyusunan Skala Psikologi. Yogyakarta, Indonesia: Pustaka Pelajar, (2018)

[22] R. A. et al. Baer, "Construct Validity of the Five Facet Mindfulness Questionaire in meditating and Non Meditating Samples.," Assesment, vol. volume 15, no. No.3, (2008)

[23] S. O. Bedoe, A. E. \& Murphy, "Does mindfulness decrease stress and emphaty among nursing student.," J. Nurs. Educ., vol. 43, no. (7), pp. 305-317, (2004)

[24] P. G. Stanley, M. dan Beare, Buku Ajar Keperawatan Gerontik. Dialih bahasakan oleh Nety Juniarti, S. Kp, Sari Kurnianingsih, S.Kp. Jakarta: Penerbit Buku Kedokteran ECG, (2006)

[25] S. Hamilton, N.A., Kitzman, H., Guyotte, "Enhancing health and emotion: Mindfulness as a missing link between cognitive therapy and positive psychology. Journal of Cognitive Psychotherapy," J. Cogn. Psychother. An Int. Q., Vol. 20, no. 2, pp. 123 134, (2006)

[26] E. B. Hurlock, Psikologi perkembangan: suatu pendekatan sepanjang rentang kehidupan. (Penerjemah: Istiwadayanti dan Soedjarmo). Jakarta: Penerbit Erlangga, (1991) 